\title{
Retraction
}

The article titled, "Pulmonary functions in pregnancy complicated with anemia", published in the International Journal of Research in Medical Sciences, Volume 2, Issue 4, 2014, Pages 1431-1437, DOI: 10.5455/23206012.ijrms20141135 is being retracted. It has been observed that the article contains several overlapping text sections from a previous published article titled, "Dynamic lung functions in pregnancy complicated with anemia" published in the printed version of Orissa Medical Journal, Volume 34 Issue 1, 2014, pages 103-110. 


\title{
Research Article
}

\section{Pulmonary functions in pregnancy complicated with anemia}

\author{
Subhalaxmi Dash*, Sudhanshu Sekhara Nanda, Ashok Kumar Behera
}

Department of Obstetrics \& Gynecology, MKCG Medical College, Berhampur, Ganjam, Odisha, India

\author{
Received: 11 August 2014 \\ Accepted: 5 September 2014

\section{*Correspondence:} \\ Dr. Subhalaxmi Dash, \\ E-mail: drsubhalaxmidash@gmail.com
}

Copyright: () the author(s), publisher and licensee Medip Academy. This is an open-access article distributed under the terms of the Creative Commons Attribution Non-Commercial License, which permits unrestricted non-commercial use, distribution, and reproduction in any medium, provided the original work is properly cited.

\section{ABSTRACT}

Background: The aim of the present study was to find out the variation of pulmonary function parameters in different trimesters of pregnancy as well as variation according to severity of anemia in each trimester.

Methods: The present case control study was carried out in the post-graduate department of obstetrics \& gynecology, M.K.C.G. medical college and hospital, Berhampur, during the period from October 2012 to October 2013. This study entitled "Pulmonary functions in pregnancy complicated with anemia", embodies the pulmonary functions of 60 anemic pregnant females (study group) and 100 healthy pregnant females (control) in different trimesters of pregnancy. The pulmonary function parameters, which were studied, are FVC, FEV $1, \mathrm{FEV}_{1} / \mathrm{FVC}, \mathrm{FEF}_{25-75 \%}$, PEFR and MVV in both the study and control group.

Results: Comparing the variation with advancing gestation in study and control, it was seen that FVC, FEV 1 , $\mathrm{FEV}_{1} / \mathrm{FVC}$ and $\mathrm{FEF}_{25-75 \%}$ showed no significant alteration. With increasing severity of anemia compared to controls, $\mathrm{FVC}, \mathrm{FEV}_{1}, \mathrm{PEFR}$ and MVV values reduce significantly. As $\mathrm{FEF}_{25-75 \%}$ is not effort dependent, it shows no significant variation.

Conclusion: Thus from this study, it can be concluded that moderate to severe anemia in pregnancy can adversely affect pulmonary functions. Hence nutritional anemia in early pregnancy should be provided with iron supplements in order to prevent adverse obstetric outcomes.

Keywords: Pulmonary function test, Anemia, Pregnancy

\section{INTRODUCTION}

India accounts for more than $20 \%$ of global maternal and child deaths, ${ }^{1}$ with a Maternal Mortality Rate (MMR) of 212 per 100000 live births and Infant Mortality Rate (IMR) of 47 per 1000 live births, in 2010-11. ${ }^{2}$

Anemia underplays a key role for the development of different complications, the long term effect of which, is reflected in the mother and its fetus. Hence the impact of anemia is immense and extreme. The estimated prevalence of anemia in pregnant women is $14 \%$ in developed, $51 \%$ in developing countries and $65-75 \%$ in India..$^{3,4}$ The global prevalence of the same is $55.9 \% .^{5}$
Pregnancy produces alteration in functions of all the systems of the body. Some of those alterations are mostly adaptive and pregnancy represents one of the best examples of selective adaptation in terms of respiratory physiology. ${ }^{6}$

The changes in respiratory physiology are due to increasing size of the fetus with advancing gestation, which constitutes a mechanical impediment to normal process of ventilation. ${ }^{7,8}$ Also an elevated level of progesterone observed during pregnancy may have an effect on the activity of the respiratory drive..$^{9,10}$

The knowledge of the expected or desired changes in pulmonary parameters is fundamental to understanding 
of, how the anemic state that affect pregnancy and vice versa. ${ }^{11}$ It helps to manage the course and the gestational outcome for a safe delivery and fitness for anesthesia. ${ }^{12}$ Lots of work has been reported to show the changes in pulmonary function test during different trimesters of pregnancy. ${ }^{13-15}$ But very few works has been documented till date to evaluate the dynamic lung function parameters in pregnancy complicated with anemia.

So in this present study, an attempt has been made to justify the complications of anemia in pregnancy on the respiratory system, by comparing pulmonary function tests in anemic pregnant and healthy pregnant women as control.

\section{METHODS}

The present case control study was carried out in the post-graduate department of obstetrics \& gynecology, M.K.C.G. medical college and hospital, Berhampur, during the period from October 2012 to October 2013.

The study included 60 anemic pregnant women within the age group of 20-40 years. Out of which 16 subjects were in the first trimester, 25 in the second and 19 in the third trimester. It also included 100 age matched normal healthy pregnant women, of which 32 were in the first, 33 in the second and 35 subjects in the third trimester. All of them were selected from antenatal clinic of obstetrics and gynecology department of M.K.C.G. medical college and hospital, at random. The anemic patients had hemoglobin level in the range of $10.9 \mathrm{~g} / \mathrm{dl}$ to $4 \mathrm{~g} / \mathrm{dl}$. The subjects were further sub-divided into mild, moderate and severe anemic groups based on WHO criteria for hemoglobin ${ }^{16}$ (Mild: 10-10.9 g/dl, moderate: 7-10 g/dl, severe: 4-6.9 $\mathrm{g} / \mathrm{dl})$.

After taking consent, all the subjects were thoroughly interrogated. Detailed history was taken and thorough medical examinations were done. The test was done in a fixed time schedule in the forenoon between 10 am to 12 noon, to avoid diurnal variation. The pulmonary function was assessed in all subjects by Medspiror having Helios 401 Software [by Recorders \& Medicare Systems (RMS), Chandigarh, Version 0.1, Jan 2004]. Dynamic lung function parameters: FVC, $\mathrm{FEV}_{1}, \mathrm{FEV}_{1} / \mathrm{FVC}, \mathrm{FEF}_{25-75 \% \text {, }}$ PEFR and MVV were recorded.

\section{Statistical analysis}

All the data were expressed as Mean \pm SD. The parameters were compared in both the normal and anemic groups by the $\mathrm{p}$ value, calculated by unpaired students 't'test. A level of $\mathrm{P}$ value $<0.05$ was used to indicate statistical significance in all analyses. ANOVA (Analysis of Variance) was used to compare the parameters between three trimesters of pregnancy and between different degrees of anemia in pregnancy. Pearson's correlation analysis by correlation coefficient ' $r$ ' was performed to assess the relationship between pregnancy complicated with degrees of anemia and respiratory parameters. All the data was analyzed using SPSS for Windows (SPSS Software package, version 16, SPSS Inc, Chicago, Illinois).

\section{RESULTS}

Comparisons of the dynamic lung function parameters like FVC, $\mathrm{FEV}_{1}, \mathrm{FEV}_{1} / \mathrm{FVC}, \mathrm{FEF}_{25-75 \%}$, PEFR and MVV were done in each trimester of pregnancy between the study group and control group (Table 1-5). Statistical test ANOVA was applied to compare.

The study group was further divided into mild, moderate and severe anemia in each trimester. The selected parameters were compared between control and mild, moderate, severe anemia in each trimester of pregnancy separately (Table 6-9). Comparison was done using ANOVA.

There is decrease of the FVC, PEFR and MVV values in anemic pregnant than normal pregnant women and this is highly significant statistically $(\mathrm{P}<0.01)$. The decrease of $\mathrm{FEV}_{1}$ is only significant. $\mathrm{FEV}_{1} / \mathrm{FVC}$ ratio increases significantly in study subjects than control subjects. $\mathrm{FEF}_{25-75 \%}$ shows no significant difference among anemic and normal pregnant females (Table 1).

There were statistically highly significant reduction of FVC, FEV ${ }_{1}$, PEFR and MVV values in anemic pregnant females compared to controls. $\mathrm{FEV}_{1} / \mathrm{FVC}$ is increased in study group than control, which is also statistically highly significant. Decline in $\mathrm{FEF}_{25-75 \%}$ values is not significant (Table 2). The decline of FVC, FEV 1, PEFR and MVV values in anemic pregnancy than normal pregnancy are highly significant statistically, but $\mathrm{FEF}_{25-75 \%}$ shows no significant variation. $\mathrm{FEV}_{1} / \mathrm{FVC}$ increases significantly in study than control group (Table 3). There were no significant variations of $\mathrm{FVC}, \mathrm{FEV}_{1}, \mathrm{FEV}_{1} / \mathrm{FVC}$ and $\mathrm{FEF}_{25-75 \%}$ values from $1^{\text {st }}$ to $3^{\text {rd }}$ trimester in study group. But PEFR and MVV are highly significantly reduced from $1^{\text {st }}$ to $3^{\text {rd }}$ trimester in study group (Table 4). The variation of $\mathrm{FVC}, \mathrm{FEV}_{1}, \mathrm{FEV}_{1} / \mathrm{FVC}$ and $\mathrm{FEF}_{25-75 \%}$ values in the three trimesters, in control group are not statistically significant. However, PEFR and MVV values decline progressively from $1^{\text {st }}$ to $3^{\text {rd }}$ trimester, which is statistically highly significant (Table 5).

There is highly significant reduction in FVC, PEFR and $\mathrm{MVV}$ and significant reduction in $\mathrm{FEV}_{1}$ from control to severe anemic pregnant females.FEV $1 / \mathrm{FVC}$ and $\mathrm{FEF}_{25-75 \%}$ values however, show no significant variation in between the groups (Table 6). There is statistically highly significant reduction in $\mathrm{FVC}, \mathrm{FEV}_{1}, \mathrm{PEFR}$ and $\mathrm{MVV}$ values and only significant increase of $\mathrm{FEV}_{1} / \mathrm{FVC}$ from control to severe anemic subjects. But $\mathrm{FEF}_{25-75 \%}$ shows no significant reduction (Table 7). There is statistically highly significant reduction of $\mathrm{FVC}, \mathrm{FEV}_{1}, \mathrm{PEFR}$ and $\mathrm{MVV}$ values and significant increase of $\mathrm{FEV}_{1} / \mathrm{FVC}$ from control to severe anemic pregnant females. $\mathrm{FEF}_{25-75 \%}$ 
values show reduction but are not statistically significant (Table 8).There is positive correlation of hemoglobin with $\mathrm{FVC}, \mathrm{FEV}_{1}, \mathrm{FEF}_{25-75 \%}$, PEFR and MVV values, but negative correlation with $\mathrm{FEV}_{1} / \mathrm{FVC}$ (Table 9).

Table 1: Dynamic lung function parameters of $1^{\text {st }}$ trimester pregnant females.

\begin{tabular}{|c|c|c|c|c|c|c|}
\hline & FVC (Lt) & $\mathrm{FEV}_{1}(\mathrm{Lt})$ & FEV $1 / F V C(\%)$ & $\mathrm{FEF}_{25-75 \%}(\mathrm{~L} / \mathrm{sec})$ & PEFR (L/Sec) & MVV (L/min) \\
\hline $\begin{array}{l}\text { Study group } \\
(\mathrm{n}=16)\end{array}$ & $2.2688 \pm 0.3040$ & $1.9475 \pm 0.2713$ & $85.9968 \pm 2.4871$ & $2.5362 \pm 0.3369$ & $4.9188 \pm 0.6098$ & $63.4375 \pm 9.2518$ \\
\hline $\begin{array}{l}\text { Control group } \\
(\mathrm{n}=32)\end{array}$ & $2.5394 \pm 0.2755$ & $2.1325 \pm 0.2649$ & $83.8978 \pm 3.2832$ & $2.6728 \pm 0.2774$ & $5.6766 \pm 0.4053$ & $72.9062 \pm 6.8831$ \\
\hline 't'value & 2.970 & 2.263 & 2.250 & 1.496 & 5.139 & 3.998 \\
\hline $\mathrm{P}$ value & 0.005 & 0.028 & 0.029 & 0.142 & 0.000 & 0.000 \\
\hline Significance & $\mathrm{HS}^{*}$ & $\mathrm{~S}$ & $\mathrm{~S}$ & NS & $\mathrm{HS}^{*}$ & HS* \\
\hline
\end{tabular}

[P $>0.05$ - Not Significant (NS), P $<0.05$ - Significant (S), P <0.01 - Highly Significant (HS)*]

FVC: Forced vital capacity, FEV 1 : Forced expiratory Volume in first second.

$\mathrm{FEV}_{1} / \mathrm{FVC} \%$ : Ratio of $\mathrm{FEV}_{1}$ and $\mathrm{FVC}$ in percentage,

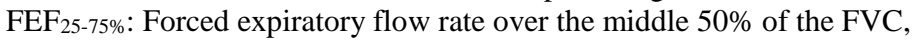

PEFR: Peak expiratory flow rate, MVV: Maximum voluntary ventilation

Table 2: Dynamic lung function parameters of $2^{\text {nd }}$ trimester pregnant females.

\begin{tabular}{|c|c|c|c|c|c|c|}
\hline & FVC (Lt) & FEV 1 (Lt) & $\mathrm{FEV}_{1} / \mathrm{FVC}(\%)$ & $\mathrm{FEF}_{25-75 \%}(\mathrm{~L} / \mathrm{sec})$ & PEFR (L/Sec) & MVV (L/min) \\
\hline $\begin{array}{l}\text { Study group } \\
(\mathrm{n}=25)\end{array}$ & $2.1936 \pm 0.3040$ & $1.9024 \pm 0.2778$ & $86.6895 \pm 2.8608$ & $2.5524 \pm 0.3639$ & $4.2332 \pm 0.5518$ & $55.40 \pm 8.7178$ \\
\hline $\begin{array}{l}\text { Control group } \\
(\mathrm{n}=33)\end{array}$ & $2.5055 \pm 0.2491$ & $2.1176 \pm 0.2457$ & $84.4196 \pm 3.2746$ & $2.6945 \pm 0.2445$ & $5.1197 \pm 0.4609$ & $67.7576 \pm 6.210$ \\
\hline 't' value & 4.293 & 3.121 & 2.758 & 1.778 & 6.661 & 6.307 \\
\hline $\mathrm{P}$ value & 0.000 & 0.003 & 0.008 & 0.081 & 0.000 & 0.000 \\
\hline Significance & $\mathrm{HS}^{*}$ & HS* & HS* & NS & $\mathrm{HS}^{*}$ & $\mathrm{HS}^{*}$ \\
\hline
\end{tabular}

[P $>0.05$ - Not Significant (NS), P $<0.05$ - Significant (S), P $<0.01$ - Highly Significant (HS)*]

Table 3: Dynamic lung function parameters of $3^{\text {rd }}$ trimester pregnant females.

\begin{tabular}{|c|c|c|c|c|c|c|}
\hline & FVC (Lt) & $\mathrm{FEV}_{1}(\mathrm{Lt})$ & $\mathrm{FEV}_{1} / \mathrm{FVC}(\%)$ & $\mathrm{FEF}_{25-75 \%}(\mathrm{~L} / \mathrm{sec})$ & PEFR (L/Sec) & MVV (L/min) \\
\hline $\begin{array}{l}\text { Study group } \\
(\mathrm{n}=19)\end{array}$ & $2.1263 \pm 0.2883$ & $1.8711 \pm 0.2747$ & $87.932 \pm 3.8222$ & $2.5853 \pm 0.3489$ & $3.690 \pm 0.5646$ & $51.00 \pm 8.6087$ \\
\hline $\begin{array}{l}\text { Control group } \\
(\mathrm{n}=35)\end{array}$ & $2.4617 \pm 0.2631$ & $2.097 \pm 0.2453$ & $85.1438 \pm 3.1343$ & $2.7023 \pm 0.2778$ & $4.6714 \pm 0.5458$ & $62.714 \pm 6.0758$ \\
\hline 't'value & 4.325 & 3.101 & 2.888 & 1.350 & 6.235 & 5.826 \\
\hline $\mathrm{P}$ value & 0.000 & 0.003 & 0.006 & 0.183 & 0.000 & 0.000 \\
\hline Significance & HS* & HS* & $\mathrm{HS}^{*}$ & NS & HS* & HS* \\
\hline
\end{tabular}

[P $>0.05$ - Not Significant (NS), P $<0.05$ - Significant (S), P $<0.01$ - Highly Significant (HS)*]

Table 4: Comparison of dynamic lung function parameters between 3 trimesters in study group ( $\mathrm{n}=60)$ (ANOVA).

\begin{tabular}{|llllll|} 
& $\begin{array}{l}1^{\text {st }} \text { trimester } \\
(\mathbf{n}=\mathbf{1 6})\end{array}$ & $\begin{array}{l}\mathbf{2}^{\text {nd }} \text { trimester } \\
(\mathbf{n}=\mathbf{2 5})\end{array}$ & $\begin{array}{l}\mathbf{3}^{\text {rd }} \text { trimester } \\
(\mathbf{n}=\mathbf{1 9})\end{array}$ & F value & $\begin{array}{l}\text { P value } \\
\text { (Significance) }\end{array}$ \\
\hline FVC $(\mathrm{L})$ & $2.27 \pm 0.34$ & $2.19 \pm 0.30$ & $2.13 \pm 0.28$ & 0.924 & $0.403(\mathrm{NS})$ \\
\hline $\mathrm{FEV}_{1}(\mathrm{~L})$ & $1.95 \pm 0.27$ & $1.90 \pm 0.28$ & $1.87 \pm 0.27$ & 0.336 & $0.716(\mathrm{NS})$ \\
\hline $\mathrm{FEV}_{1} / \mathrm{FVC}(\%)$ & $85.99 \pm 2.49$ & $86.69 \pm 2.86$ & $87.93 \pm 3.82$ & 1.775 & $0.179(\mathrm{NS})$ \\
\hline $\mathrm{FEF}_{25-75 \%}(\mathrm{~L} / \mathrm{sec})$ & $2.54 \pm 0.33$ & $2.55 \pm 0.36$ & $2.58 \pm 0.34$ & 0.090 & $0.914(\mathrm{NS})$ \\
\hline $\mathrm{PEFR}(\mathrm{L} / \mathrm{sec})$ & $4.92 \pm 0.61$ & $4.23 \pm 0.55$ & $3.69 \pm 0.56$ & 20.074 & $0.000(\mathrm{HS})^{*}$ \\
\hline $\mathrm{MVV}(\mathrm{L} / \mathrm{min})$ & $63.44 \pm 9.25$ & $55.40 \pm 8.72$ & $51.00 \pm 8.61$ & 8.775 & $0.000(\mathrm{HS})^{*}$ \\
\hline
\end{tabular}

[P $>0.05$ - Not Significant (NS), P $<0.05$ - Significant (S), P $<0.01$ - Highly Significant (HS)*] 
Table 5: Comparison of dynamic lung function parameters between three trimesters in control group $(\mathrm{n}=100)$ (ANOVA).

\begin{tabular}{|llllll|}
\hline & $\begin{array}{l}\mathbf{1}^{\text {st }} \text { trimester } \\
(\mathbf{n}=\mathbf{3 2})\end{array}$ & $\begin{array}{l}\mathbf{2}^{\text {nd }} \text { trimester } \\
(\mathbf{n}=\mathbf{3 3})\end{array}$ & $\begin{array}{l}\mathbf{3}^{\text {rd }} \text { trimester } \\
(\mathbf{n}=\mathbf{3 5})\end{array}$ & $\begin{array}{l}\text { F value } \\
\text { FVC }(\mathrm{L})\end{array}$ & $\begin{array}{l}\text { P value } \\
\text { (Significance) }\end{array}$ \\
\hline $\mathrm{FEV}_{1}(\mathrm{~L})$ & $2.54 \pm 0.28$ & $2.51 \pm 0.25$ & $2.46 \pm 0.26$ & 0.738 & $0.481(\mathrm{NS})$ \\
\hline $\mathrm{FEV}_{1} / \mathrm{FVC}(\%)$ & $83.89 \pm 3.28$ & $84.42 \pm 3.27$ & $85.14 \pm 3.13$ & 1.262 & $0.288(\mathrm{NS})$ \\
\hline $\mathrm{FEF}_{25-75 \%}(\mathrm{~L} / \mathrm{sec})$ & $2.67 \pm 0.27$ & $2.69 \pm 0.25$ & $2.70 \pm 0.28$ & 0.108 & $0.898(\mathrm{NS})$ \\
\hline $\mathrm{PEFR}(\mathrm{L} / \mathrm{sec})$ & $5.67 \pm 0.41$ & $5.12 \pm 0.46$ & $4.67 \pm 0.54$ & 37.245 & $0.000(\mathrm{HS})^{*}$ \\
\hline $\mathrm{MVV}(\mathrm{L} / \mathrm{min})$ & $72.91 \pm 6.88$ & $67.76 \pm 6.21$ & $62.71 \pm 6.07$ & 21.286 & $0.000(\mathrm{HS})^{*}$ \\
\hline
\end{tabular}

[P >0.05 - Not Significant (NS), P <0.05 - Significant (S), P <0.01 - Highly Significant (HS)*]

Table 6: Comparison of dynamic parameters between control group and study group with different degrees of anemia in $1^{\text {st }}$ trimester using ANOVA.

\begin{tabular}{|lllllll|} 
& $\begin{array}{l}\text { Control } \\
(\mathbf{n}=\mathbf{3 2})\end{array}$ & $\begin{array}{l}\text { Mild anemia } \\
(\mathbf{n = 8})\end{array}$ & $\begin{array}{l}\text { Moderate anemia } \\
(\mathbf{n}=\mathbf{5})\end{array}$ & $\begin{array}{l}\text { Severe anemia } \\
(\mathbf{n = 3})\end{array}$ & $\begin{array}{l}\text { F value } \\
\text { PV value } \\
\text { (Significance) }\end{array}$ \\
\hline FVC $(\mathrm{L})$ & $2.54 \pm 0.28$ & $2.42 \pm 0.31$ & $2.216 \pm 0.36$ & $1.96 \pm 0.16$ & 5.130 & $0.004(\mathrm{HS}) *$ \\
\hline $\mathrm{FEV}_{1}(\mathrm{~L})$ & $2.13 \pm 0.26$ & $2.05 \pm 0.258$ & $1.92 \pm 0.29$ & $1.716 \pm 0.13$ & 2.992 & $0.041(\mathrm{~S})$ \\
\hline $\mathrm{FEV}_{1} / \mathrm{FVC}(\%)$ & $83.89 \pm 3.28$ & $84.93 \pm 1.62$ & $86.69 \pm 2.87$ & $87.66 \pm 3.284$ & 2.403 & $0.080(\mathrm{NS})$ \\
\hline $\mathrm{FEF}_{25-75 \%}(\mathrm{~L} / \mathrm{sec})$ & $2.67 \pm 0.277$ & $2.59 \pm 0.337$ & $2.514 \pm 0.32$ & $2.42 \pm 0.46$ & 0.966 & $0.417(\mathrm{NS})$ \\
\hline $\mathrm{PEFR}(\mathrm{L} / \mathrm{sec})$ & $5.67 \pm 0.405$ & $5.38 \pm 0.34$ & $4.608 \pm 0.40$ & $4.20 \pm 0.44$ & 20.822 & $0.000(\mathrm{HS}) *$ \\
\hline $\mathrm{MVV}(\mathrm{L} / \mathrm{min})$ & $72.91 \pm 6.88$ & $70.37 \pm 5.18$ & $60.6 \pm 4.16$ & $49.66 \pm 4.04$ & 16.269 & $0.000(\mathrm{HS}) *$ \\
\hline
\end{tabular}

[P >0.05 - Not Significant (NS), P <0.05 - Significant (S), P <0.01 - Highly Significant (HS)*]

Table 7: Comparison of dynamic parameters between control group and study group with different degrees of anemia in $2^{\text {nd }}$ trimester using ANOVA.

\begin{tabular}{|lllllll|} 
& $\begin{array}{l}\text { Control } \\
(\mathbf{n}=\mathbf{3 3})\end{array}$ & $\begin{array}{l}\text { Mild anemia } \\
(\mathbf{n}=\mathbf{8})\end{array}$ & $\begin{array}{l}\text { Moderate anemia } \\
(\mathbf{n}=\mathbf{1 2})\end{array}$ & $\begin{array}{l}\text { Severe anemia } \\
(\mathbf{n = 5})\end{array}$ & $\begin{array}{l}\text { F value } \\
\text { P value } \\
\text { (Significance) }\end{array}$ \\
\hline FVC $(\mathrm{L})$ & $2.51 \pm 0.249$ & $2.39 \pm 0.33$ & $2.18 \pm 0.203$ & $1.88 \pm 0.234$ & 11.440 & $0.000(\mathrm{HS}) *$ \\
\hline $\mathrm{FEV}_{1}(\mathrm{~L})$ & $2.12 \pm 0.24$ & $2.05 \pm 0.32$ & $1.901 \pm 0.190$ & $1.67 \pm 0.25$ & 5.921 & $0.001(\mathrm{HS}) *$ \\
\hline $\mathrm{FEV}_{1} / \mathrm{FVC}(\%)$ & $84.42 \pm 3.27$ & $85.37 \pm 2.57$ & $86.92 \pm 2.98$ & $88.22 \pm 2.54$ & 3.495 & $0.022(\mathrm{~S})$ \\
\hline $\mathrm{FEF}_{25-75 \%}(\mathrm{~L} / \mathrm{sec})$ & $2.69 \pm 0.244$ & $2.61 \pm 0.37$ & $2.54 \pm 0.38$ & $2.49 \pm 0.37$ & 1.204 & $0.317(\mathrm{NS})$ \\
\hline $\mathrm{PEFR}(\mathrm{L} / \mathrm{sec})$ & $5.119 \pm 0.46$ & $4.79 \pm 0.33$ & $4.10 \pm 0.38$ & $3.65 \pm 0.35$ & 28.934 & $0.000(\mathrm{HS}) *$ \\
\hline $\mathrm{MVV}(\mathrm{L} / \mathrm{min})$ & $67.75 \pm 6.21$ & $65.12 \pm 6.13$ & $53.08 \pm 3.89$ & $45.40 \pm 4.27$ & 36.198 & $0.000(\mathrm{HS}) *$ \\
\hline
\end{tabular}

[P >0.05 - Not Significant (NS), P <0.05 - Significant (S), P <0.01 - Highly Significant (HS)*]

Table 8: Comparison of dynamic parameters between control group and study group with different degrees of anemia in $3^{\text {rd }}$ trimester (ANOVA).

\begin{tabular}{|lllllll|}
\hline & $\begin{array}{l}\text { Control } \\
(\mathbf{n = 3 5})\end{array}$ & $\begin{array}{l}\text { Mild anemia } \\
(\mathbf{n}=\mathbf{5})\end{array}$ & $\begin{array}{l}\text { Moderate anemia } \\
(\mathbf{n = 9})\end{array}$ & $\begin{array}{l}\text { Severe anemia } \\
(\mathbf{n}=\mathbf{5})\end{array}$ & $\begin{array}{l}\text { F value } \\
\text { FVC }(\mathrm{L})\end{array}$ & $\begin{array}{l}\text { P value } \\
\text { (Significance) }\end{array}$ \\
\hline $\mathrm{FEV}_{1}(\mathrm{~L})$ & $2.46 \pm 0.26$ & $2.358 \pm 0.30$ & $2.15 \pm 0.198$ & $1.84 \pm 0.19$ & 10.750 & $0.000(\mathrm{HS}) *$ \\
\hline $\mathrm{FEV}_{1} / \mathrm{FVC}(\%)$ & $85.14 \pm 3.13$ & $86.23 \pm 5.03$ & $88.08 \pm 1.69$ & $89.35 \pm 5.34$ & 3.508 & $0.022(\mathrm{~S})$ \\
\hline $\mathrm{FEF}_{25-75 \%}(\mathrm{~L} / \mathrm{sec})$ & $2.70 \pm 0.27$ & $2.648 \pm 0.406$ & $2.58 \pm 0.34$ & $2.52 \pm 0.38$ & 0.723 & $0.543(\mathrm{NS})$ \\
\hline $\mathrm{PEFR}(\mathrm{L} / \mathrm{sec})$ & $4.67 \pm 0.54$ & $4.436 \pm 0.25$ & $3.606 \pm 0.29$ & $3.09 \pm 0.211$ & 24.428 & $0.000(\mathrm{HS}) *$ \\
\hline $\mathrm{MVV}(\mathrm{L} / \mathrm{min})$ & $62.71 \pm 6.07$ & $60.80 \pm 4.43$ & $50.89 \pm 5.79$ & $41.4 \pm 3.36$ & 26.608 & $0.000(\mathrm{HS}) *$ \\
\hline
\end{tabular}

[P >0.05 - Not Significant (NS), P <0.05 - Significant (S), P <0.01 - Highly Significant (HS)*] 
Table 9: Correlation of hemoglobin with pulmonary function parameters.

\begin{tabular}{|ll|}
\hline $\begin{array}{l}\text { Pulmonary function } \\
\text { parameters }\end{array}$ & $\begin{array}{l}\text { Pearson correlation } \\
\text { with hemoglobin (' } r \text { ') }\end{array}$ \\
\hline FVC (L) & 0.642 \\
\hline FEV $_{1}(\mathrm{~L})$ & 0.531 \\
\hline $\mathrm{FEV}_{1} / \mathrm{FVC}(\%)$ & -0.371 \\
\hline $\mathrm{FEF}_{25-75 \%}(\mathrm{~L} / \mathrm{sec})$ & 0.325 \\
\hline $\mathrm{PEFR}(\mathrm{L} / \mathrm{Sec})$ & 0.698 \\
\hline $\mathrm{MVV}(\mathrm{L} / \mathrm{min})$ & 0.740 \\
\hline
\end{tabular}

\section{DISCUSSION}

The various dynamic lung function parameters studied in $1^{\text {st }}, 2^{\text {nd }}$ and $3^{\text {rd }}$ trimesters of pregnancy in study (Table 4) as well as control group (Table 5), shows decrease in $\mathrm{FVC}$ and $\mathrm{FEV}_{1}$ values with advancing gestation which are statistically not significant. The ratio of $\mathrm{FEV}_{1} / \mathrm{FVC} \%$ and $\mathrm{FEF}_{25-75 \%}$ values are comparable among the three trimesters of pregnancy with no statistical significance. Similar results were found by Phatak MS et al. (2003). ${ }^{17}$ This could be due to;

- A state of relative bronchodilation which might be brought about by the smooth muscle relaxing action of certain hormones such as progesterone, relaxin and corticosteroids. ${ }^{18}$

- The relative increase mobility of the thoracic cage as well as unimpaired diaphragmatic movement despite the progressive enlargement of gravid uterus may be the factors in preservation of FVC values. ${ }^{17}$

- The preservation of both the large and small airway function is the result of bronchoconstrictive effect of low alveolar $\mathrm{pCO}_{2}$ counteracted by bronchodilation, mainly produced by progesterone. ${ }^{19}$

It also reveals in present study a progressively significant reduction in PEFR values from $1^{\text {st }}$ trimester to $3^{\text {rd }}$ trimester in both study and control group (Table 4,5). These findings are comparable with many authors such as Phatak MS et al. (2003), ${ }^{17}$ Neeraj et al. (2010), ${ }^{20}$ Teli A et al. (2012), ${ }^{21}$ Bansal M etal. (2012). ${ }^{22}$

This may be attributed to a lesser force of contraction of main expiratory muscles like anterior abdominal muscles and internal intercostal muscles or could be due to mechanical effect of gravid uterus affecting vertical dimension by restricting the diaphragmatic movement.

Progressively decreased values of MVV from $1^{\text {st }}$ to $3^{\text {rd }}$ trimester of pregnancy obtained in this study in anemic and control subjects (Table 4,5) are similar to Ganeriwal SK et al. (1984) $)^{23}$ and De $\mathrm{S}$ et al. (1984). ${ }^{18}$
The decrease in MVV may be explained by over stretching of muscles of anterior abdominal wall leading to decreased force of contraction of these muscles available for expiration. Also the enlarged uterus may push the diaphragm up leading to a decreased intra pleural pressure, which will affect the amount of air drawn in the lungs in a single respiration. ${ }^{23}$

MVV was also influenced by the efficiency of the respiratory apparatus as a pump. Since this pump was at a certain mechanical disadvantage during pregnancy, the MVV might be reduced without any obstruction to the airflow. ${ }^{18}$

Comparison of lung function parameters between anemic pregnant and healthy pregnant females (Table $1,2 \& 3$ ) shows, significant reduction of FVC, FEV 1, PEFR and MVV values except $\mathrm{FEF}_{25-75 \%}$ and $\mathrm{FEV}_{1} / \mathrm{FVC}$ in the study group (Anemic), in all the three trimesters of pregnancy. $\mathrm{FEF}_{25-75 \%}$ values decline in study group compared to control, but the difference is not statistically significant. $F E V_{1} / F V C$ ratio increases significantly in study group compared to control in all three trimesters, as the decrease in FVC is more than decrease in $\mathrm{FEV}_{1}$ showing a restrictive defect. The reduction of FVC, $\mathrm{FEV}_{1}$, PEFR and MVV may be attributed to reduction of oxygen carrying capacity of blood resulting in tissue hypoxia and accumulation of intermediary products of metabolism like lactate in the tissue leading to exhaustion. So the respiratory efforts become less powerful. ${ }^{24}$

The decrease in the concentration of myoglobin and iron containing enzymes like cytochrome $\mathrm{C}$ in skeletal muscle is roughly proportional to that of hemoglobin in both mild and severe anemia. ${ }^{25}$ The resultant decrease in the work capacity due to voluntary respiratory muscles dysfunction could possibly explain the reduction in the force or effort dependent parameters like $\mathrm{FVC}, \mathrm{FEV}_{1}$, PEFR and MVV.

The comparisons of dynamic parameters were done between control group and study group with different degrees of anemia in $1^{\text {st }}$ trimester (Table 6). Using statistical test ANOVA (Table 6) the four groups (control, mild, moderate, severe) are compared. There is significant reduction in $\mathrm{FVC}, \mathrm{FEV}_{1}$, PEFR and MVV values with increasing degree of anemia. $\mathrm{FEV}_{1} / \mathrm{FVC}$ values increase but are not statistically significant. The declines in $\mathrm{FEF}_{25-75 \%}$ values are also not significant. The PFT parameters between control group and study group with mild, moderate and severe anemia in $2^{\text {nd }}$ trimester are compared (Table 7). ANOVA was used to compare the four groups. Studying the 'F' value and $\mathrm{P}$ value it is seen that, there is highly significant lowering of FVC, $\mathrm{FEV}_{1}$, PEFR and MVV with increasing severity of anemia. $\mathrm{FEV}_{1} / \mathrm{FVC}$ increase significantly, but no significant change in $\mathrm{FEF}_{25-75 \%}$ is seen. The comparison 
between study group (mild, moderate and severe anemia) and control group in $3^{\text {rd }}$ trimester was studied (Table 8). By studying the ANOVA, it shows statistically highly significant lowering of $\mathrm{FVC}, \mathrm{FEV}_{1}, \mathrm{PEFR}$ and $\mathrm{MVV}$ values. $\mathrm{FEV}_{1} / \mathrm{FVC}$ increases only significantly, but no significant alteration in $\mathrm{FEF}_{25-75 \%}$. The correlation of hemoglobin with dynamic pulmonary function parameters (Table 9) shows positive correlation of hemoglobin with FVC, $\mathrm{FEV}_{1}, \mathrm{FEF}_{25-75 \%}$, PEFR and MVV but negative correlation with $\mathrm{FEV}_{1} / \mathrm{FVC}$. With increasing severity of anemia compared to controls, FVC, FEV 1 , PEFR and MVV values reduce significantly. This may be because anemia causes weakness of the main respiratory muscles due to tissue hypoxia, accumulation of lactates $\&$ metabolic products, deficiency of myoglobin \& iron containing enzyme cytochrome C. As $\mathrm{FEF}_{25-75 \%}$ is not effort dependent, it shows no significant variation. So with decreasing hemoglobin, all the parameters decrease showing positive correlation except $\mathrm{FEV}_{1} / \mathrm{FVC}$ in percentage which increase due to restrictive defect showing negative correlation with hemoglobin. Thus from this study, it can be concluded that moderate to severe anemia in pregnancy can adversely affect pulmonary functions. Hence nutritional anemia in early pregnancy should be provided with iron supplements in order to prevent adverse obstetric outcomes. To the best of knowledge, this is the first study of its kind to demonstrate the relationship between different degrees of anemia and pulmonary function in pregnancy. Therefore the findings require further studies in this field.

\section{ACKNOWLEDGEMENTS}

The authors are thankful to the HOD (Dept. of obstetrics \& gynecology) and HOD (Dept. of physiology) M.K.C.G. medical college, who gave constant guidance to conduct the study.

Funding: No funding sources Conflict of interest: None declared

Ethical approval: The study was approved by the institutional ethics committee

\section{REFERENCES}

1. WHO, UNICEF \& UNFPA. Maternal mortality in 2000. In: WHO, eds. WHO Document. Geneva: WHO; 2004: 1-30.

2. Census of India. Maternal mortality ratio \& infant mortality rate. SRS Bull. 2011 Dec;46(1):1-20.

3. De Mayer EM, Tegman A. Prevalence of anemia in the world. World Health Organ Qlty. 1998;38;30216.

4. WHO. The prevalence of anemia in women. In: WHO, eds. WHO IDWNM 922. Geneva: WHO; 1992: 1-99.

5. Toteja GS, Singh P. Dhillon BS, Saxena BN, Ahmed FU, Singh RP, et al. Prevalence of anemia among pregnant women and adolescent girls in 16 districts of India. Food Nutr Bull. 2006;27(4):311-5.
6. Chhabra S, Nangia V, Ingley KN. Changes in Respiratory function tests during pregnancy. Indian J Physiol Pharmacol. 1988;32:56-60.

7. Pandya KD, Chandwani S, Desai CA, Dadlani AG. Study of vital capacity and timed vital capacity in normal non-pregnant and pregnant women. J Obstet Gynecol India. 1984;36:1053-7.

8. Saxena SC, Rao VSC, Mudgal SA. Study of pulmonary function tests during pregnancy. J Obstet Gynecol India. 1979;29:993-5,

9. Contreras G. Gutierrez M, Beroiza T, Fantin A, Oddo H, Villarroel L, et al. Ventilatory drive and respiratory muscle function in pregnancy. Am Rev Respir Dis. 1991;144;837-41.

10. Garcia-Rio F, Pino JM, Gomez L, Alvares-Sala R, Villasante C, Villamor J. Regulation of breathing and perception of dyspnea in healthy pregnant women. Chest. 1996;110:446-53.

11. Elkus R, Popovich J Jr. Respiratory physiology in pregnancy. Clin Chest Med. 1992;13:555-65.

12. Mokkapati R. Prasad EC, Venkatraman, Fatima K. Ventilatory functions in pregnancy. Indian J Physiol Pharmacol. 1991;35:237-40.

13. Gazioglu K. Kaltreider NL, Rosen M, Yu PN. Pulmonary function during pregnancy in normal woman and in patients with cardiopulmonary disease. Thorax. 1970;25:445-50.

14. Baldwin GR, Moorthi DS, Whelton JA, Mac Donnel KF. New lung functions and pregnancy. Am J Obstet Gynecol. 1977; 127:235-9.

15. Liberatore SM, Pistelli R, Patalano F, Moneta E, Incalzi R, Ciappi G. Respiratory function during pregnancy. Respiration. 1984;46:145-50.

16. World Health Organization. Preventing and controlling iron deficiency anaemia through primary health care. In: DeMaeyer EM, Dallman PGurney, JM, Hallberg L, Sood SK, Srikantia SG, eds. A Guide for Health Administrators and Programme Managers. Geneva: WHO Publications; 1989: 1-58.

17. Pathak MS, Kurhade GA. A longitudinal study of antenatal changes in lung function tests and importance of postpartum exercises in their recovery. Indian J. Physiol Pharmacol. 2003;47(3):352-6.

18. De Surekha, Bhargava RP, Benawri S. Longitudinal ventilatory function (Static and dynamic) studies during different trimesters in pregnant women. J Obstet Gynecol India. 1984;36:812-6.

19. Das TK, Jana H. Maternal airways function during normal pregnancy. Indian J Med Sci. 1991;45:2657.

20. Neeraj, Sodhi Candy, Pramod J, Singh J, Kaur V. Effect of advanced uncomplicated pregnancy on pulmonary function parameters of North Indian subjects. Indian J Physiol Pharmacol. 2010;54(1):69-72.

21. Teli A, Bagali S, Aithala M. A study of FVC, PEFR and MEP in different trimesters of pregnancy. Int $\mathrm{J}$ Biomed Adv Res. 2012;03(08):648-52. 
22. Bansal M, Goyal M, Dhilon JK, Kaur P. Longitudinal study of peak expiratory flow rate in pregnant women. NJIRM. 2012;3(1):34-8.

23. Ganeriwal SK, Deshpande DR, Reddy BV, Shaikh RM. Effect of pregnancy on pulmonary ventilation. J Obstet Gynecol India. 1984;36:639-41.

24. Singhal U, Saxena K. Effect of anaemia on respiratory and metabolic parameters during III $^{\mathrm{rd}}$ trimester of pregnancy. Indian J Physiol Pharmacol. 1987;31(2):130-5.

25. Dutt SN, Yeshwanth M, Raghuveer TS. Effect of iron deficiency anaemia on pulmonary function in children. Lung India. 1944;12(4):168-73.

DOI: $10.5455 / 2320-6012 . i j r m s 20141135$

Cite this article as: Dash S, Nanda SS, Behera AK. Pulmonary functions in pregnancy complicated with anemia. Int J Res Med Sci 2014;2:1431-7. 